\title{
FLORISTIC COMPOSITION AND BIOLOGICAL SPECTRUM OF BARA GALI, ABBOTTABAD
}

\author{
Adeela Bibi ${ }^{1 凶}$, Zafar Jamal ${ }^{2}$, Syed Hasnain shah ${ }^{3}$, Abbas Hussain Shah ${ }^{4}$, Azhar Mehmood ${ }^{4}$ \\ ${ }^{1}$ Department of Botany, Hazara University Mansehra-21300, Khyber Pakhtunkhwa, Pakistan \\ 2 Department of Botany, Govt Post Graduate College Abbottabad Khyber Pakhtunkhwa,Pakistan \\ ${ }^{3}$ Department of Environmental Science , Hazara University Mansehra-21300, Khyber Pakhtunkhwa, Pakistan \\ ${ }^{4}$ Department of Botany, Govt Post Graduate Collage, Mandian Abbottabad Khyber Pakhtunkhwa, Pakistan
}

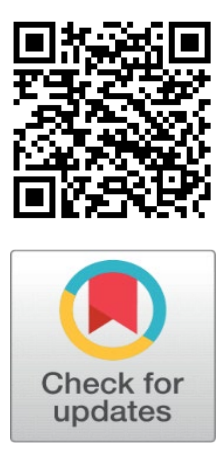

Received 17 November 2021

Accepted 5 December 2021

Published 31 December 2021

CorrespondingAuthor

Adeela Bibi, adeelabibi4@gmail.com

DOI

10.29121/granthaalayah.v9.i12.2021 .4413

Funding: This research received no specific grant from any funding agency in the public, commercial, or not-for-profit sectors.

Copyright: (C) 2021 The Author(s). This is an open access article distributed under the terms of the Creative Commons Attribution License, which permits unrestricted use, distribution, and reproduction in any medium, provided the original author and source are credited.

\section{ABSTRACT}

Floristic composition and Phytosociological studies on the flora of Bara Gali District Abbottabad, Pakistan was conducted. The altitudinal range of the Bara Gali is from 21002370 meter. From the study area 50 species belong to 33 families were recorded. Herbaceous flora was dominant with 35 species, shrubs with 10 species and tree with 5 species. Asteraceae was dominant having 6 species. Microphyll dominant leaf size spectra and hemicryptophytes were dominant life form in the study area. This study provides information about the floristic composition of Bara Gali.

Keywords: Floristic Composition, Biological Spectrum, Bara Gali

\section{INTRODUCTION}

Floristic composition is the aggregation of species that are present in a region Kent (2011). The knowledge of the floristic composition of an area is a requirement for any ecological studies. To conduct ecological study of specific vegetation in given area the first step is to determine the facts as they exist on the ground (McCune et al., 2002). Floristic composition of any area provides information about the distribution of plants and ecological zones. To envisage the vegetation of an area, it is important to see the plants' life form Shimwell (1971). Leaf size spectra and life form reveal the environmental conditions of the habitat Todoria et al. (2010). The life form studies are indicator of phyto-climatic conditions Batalha and Martins (2004). The life forms of species point out the adjustment of perennating buds to environmental conditions Nautiyal et al. (2001). The biological spectrum was described by Raunkiær in 1934. How plants protect perennating buds for coming seasons in unfavorable condition Malik et al. (2007).

\section{STUDY AREA}

Bara Gali is situated in Galiyat, District Abbottabad, Khyber Pakhtunkhwa at altitude of 2100-2370 meters. There are numerous mountains stations in that area. Bara Gali is at the distance of 16 miles from Murree. Bara Gali is known for its scenic prettiness, and pleasant climate, due to its position at higher altitude. It is located at the distance of about one hour drive away from Abbottabad. The climate of Bara Gali from September to April remains cooler. Snow fall take place during winter above 3,100 feet altitude. The Bara Gali is home of various species of birds, insects, butterflies and other animals. Monkeys are also found in the forest of Bara Gali. 


\section{MATERIALS AND METHODS}

The area of the Bara Gali was chosen for floristic study. The study area was visited frequently for data collection. The apparatuses were used during plant collection, like GPS twigs cutter, and polythene bags. The data was documented in the field not book. Collected plants specimens were properly tagged. Preserved plants specimens were identified with the help of flora of Pakistan.

\subsection{SOIL SAMPLING}

One kilogram soil samples were collected up to a depth of $15 \mathrm{~cm}$. The soil was kept in polythene bags and labeled. The soil samples were chemically and physically analyzed at Baffa Research Station, district Mansehra. The potassium, pH, phosphorus, nitrogen and organic matters were analyzed. Hydrometer technique was used for soil texture Moodi et al. (1959). Organic matter was determined with the method given by black Black (1965) method. The nitrogen sample was resoluted by Kjelaahl digention technique and available phosphorus was determined by Olsen method (Olsen, 1954).

\subsection{VEGETATION SAMPLING}

Quadrate method was used for sampling the vegetation. The size of the quadrate was $5 \times 2 \mathrm{~m}$ for shrubs, $10 \mathrm{x} 2 \mathrm{~m}$ for trees and $0.5 \times 0.5 \mathrm{~m}$ for herbs (Malik, 1986). Iron nails were used to making quadrates. The desired shape and size quadrates were laid down by fining nails at 4 points. At least 15-20 quadrates were taken at the pauses of 12 steps between each quadrate. Then after establishment of quadrates all the plant species inside were recorded. Then number of individuals of each plant species were calculated, their covers were measured with the help of measuring tapes.

\subsection{RESULTS}

There was total 50 species belong to 33 families out of which 5 were trees species, 10 were shrubs and 35 were herbs investigated in the study area (Table 1. Figure 1). Asteraceae were dominant with 6 species, then Roseaceae with 4 species followed by Pteridaceae, Caprifloreaceae with 3 species each. Polygonaceae, Labiateace, Pinaceae, Ramanculceae, Poaceae were found with 2 species each (Figure 2, Table 1).

Remaining 24 families had one species each. Seven life form classes were recorded from the study area in which hemicrytophytes was dominant life form (27.4\%) then nanophenerophytes (25.4\%), therophytes (17.6\%) megaphanerophyte (9.8\%) chamaephyte $(7.8 \%)$ geophoyte $(5.8 \%)$ and mesophanerophyte (3.9\%) (Figure 3).

It was observed in study area that the Microphyll 52.9\%, were dominant Nanophyll 23.5\%, Mesophyll were 11.7\%. Leptophyll were 9.8\%, (Figure 4).

\begin{tabular}{|c|c|c|c|}
\hline Name of Species & Family & Life Form & Leaf Spectra \\
\hline Aesculus indica (Wall ex. Camb) & Hippocastancea & MP & $\mathrm{Me}$ \\
\hline Juglans regia L. & Juglandaceae & MP & $\mathrm{Me}$ \\
\hline Quercus incana Roxb & Fagaceae & MP & $\mathrm{Me}$ \\
\hline Cedrus deodara (Lamb)G.Don & Pinaceae & MP & $\mathrm{L}$ \\
\hline
\end{tabular}


Floristic Composition and Biological Spectrum of Bara Gali, Abbottabad

\begin{tabular}{|c|c|c|c|}
\hline Pinus wallichiana A.B.Jackson & Pinaceae & MP & $\mathrm{L}$ \\
\hline Berberis lycium Royle & Berberidaceae & $N P$ & $N$ \\
\hline Viburnum grandiflorum Wall. ex DC. & Caprifoliaceae & $N P$ & $M e$ \\
\hline Indigofera heterantha Wall ex.Brandis & Pailionaceae & $N P$ & $M i$ \\
\hline Sarcococca sligna D.Don. (Muell) & Buxacaeae & $N P$ & $N P$ \\
\hline Rosa indica L. & Rosaceae & $N P$ & $L$ \\
\hline Rubus fruticosus $L$. & Rosaceae & $N P$ & MI \\
\hline Hypercum perforatum L. & Hypericaceae & $N P$ & $M I$ \\
\hline Lonicera quinquelocularis Hard. & Caprifloreace & $M e$ & MI \\
\hline Melia tomentosa Kurz & Meliaceae & $N P$ & $M I$ \\
\hline Centaurea calycitrapa $\mathrm{L}$. & Asteraceae & NP & MI \\
\hline Urtica dioca $\mathrm{L}$. & Urticaecce & $\mathrm{Np}$ & MI \\
\hline Adiantum capillus-venris $\mathrm{L}$. & Pteridaceae & G & $N$ \\
\hline Oxalis carniculata $\mathrm{L}$. & Onagracea & $H$ & $M I$ \\
\hline Arisaema flavum Schott & Asteraceae & $T h$ & $M i$ \\
\hline Artemisia maritima L.Wallich & Asteraceae & $T h$ & $M i$ \\
\hline Plantago ovata Forssk. & Plantaginaceae & $H$ & $M i$ \\
\hline Asparagus filicinus D.DON & Asparagaceae & $T h$ & $M i$ \\
\hline Viola biflora L. & Violaceae & $H$ & Mi \\
\hline Primula denticulata Sm. & Primulaceae & $H$ & $M i$ \\
\hline Rumex hastatus D.Don. & Polygonaceae & $H$ & $N$ \\
\hline Mentha arvensis $L$. & Labiateae & $N p$ & $N$ \\
\hline Hedra nepalensis K.Koch & Araliaceae & $H$ & MI \\
\hline Fragaria nubicola Lindnl & Rosaceae & $H$ & $M i$ \\
\hline Euphorbia heliscopia L. & Euphorbiacea & $T h$ & MI \\
\hline Gerenium himalayense Klotzsch & Gereniaceae & $T H$ & $N$ \\
\hline Polygontum multiflorum $L$. & Polygonaceae & $\mathrm{CH}$ & MI \\
\hline Dryopteris stewartii Fraser-Jenk. & Pteridaceae & $G$ & $N$ \\
\hline Podophyllum emodii Wall ex. Royle & Podophyllaceae & $H$ & $M i$ \\
\hline Conyza canadensis $L$. Corgn & Asteraceae & $H$ & $M i$ \\
\hline Cynodan dactylon (L) Pers & Poaceae & $\mathrm{CH}$ & $L$ \\
\hline Ranunculus muricatus $L$. & Raunculacea & $H$ & MI \\
\hline Citrullus colocynthis (L.) Schrad & Cucurbitaceae & TH & MI \\
\hline Onychium contiguum Hope & Pteridaceae & G & $L$ \\
\hline Chrysanthemum leucanthemum J. & Asteraceae & $\mathrm{TH}$ & $N$ \\
\hline Vallarina jatamansi Wall & Vallerianaceae & $\mathrm{H}$ & $M i$ \\
\hline Dioscorea deltoidea Wall & Dioscoraceae & NP & MI \\
\hline Cynoglossum officinale L. & Boraginaceae & $\mathrm{TH}$ & $N$ \\
\hline Geum elatum D.Don & Rosaceae & $\mathrm{H}$ & $M i$ \\
\hline Abelia triflora $\mathrm{R} . \mathrm{Br}$ & caprifloraceae & NP & $N$ \\
\hline Sonchus asper (L.) Hil & Asteraceae & $\mathrm{TH}$ & MI \\
\hline Aquvlegia vulgaris (Linn) & Ranunculaceae & $\mathrm{H}$ & $M I$ \\
\hline Calanthe plantagineae $\mathrm{L}$. & Orchidaceae & $\mathrm{H}$ & $M I$ \\
\hline Nepta erecta (Benth) & Labiateae & NP & $N$ \\
\hline Origanum vulgare L. & Labiateae & $\mathrm{TH}$ & $N$ \\
\hline Skimmia laureola (DC.) Sieb. \& Zuc & Rutaceae & NP & $N$ \\
\hline
\end{tabular}




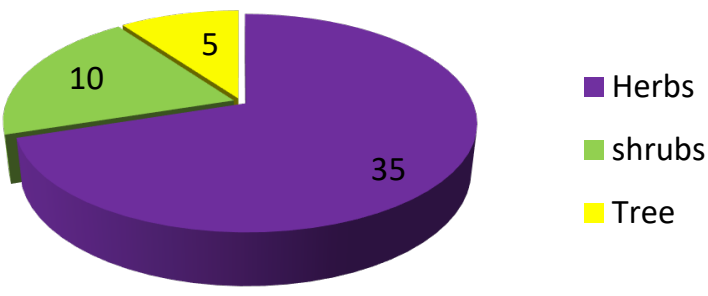

Figure 1 Plant habit documented from the study area

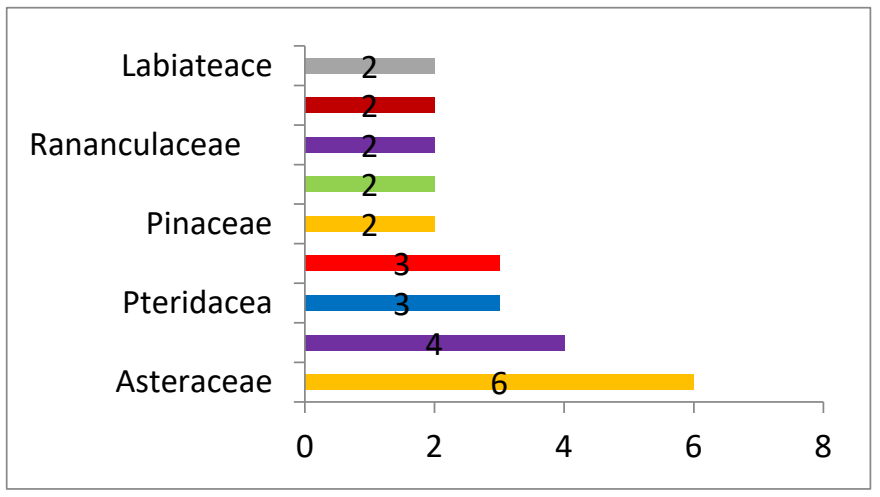

Figure 2 Graphical Representation of dominant Plant Families

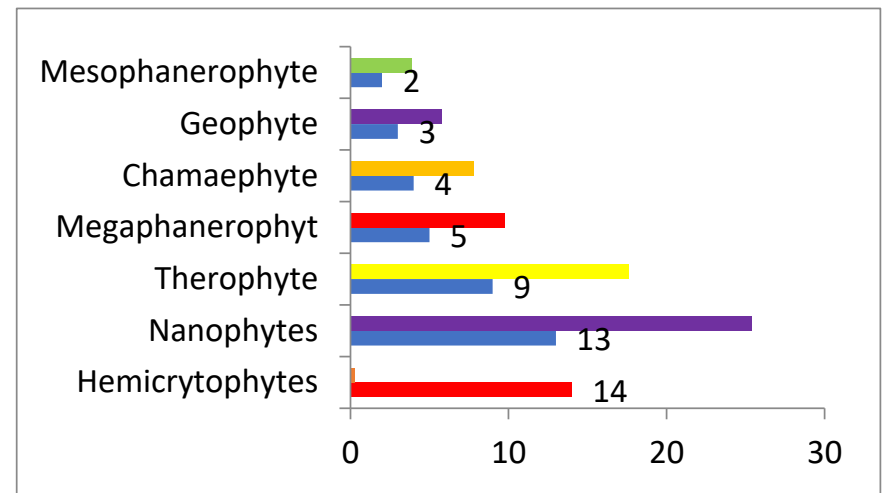

Figure 3 Life form recorded from Bara Gali

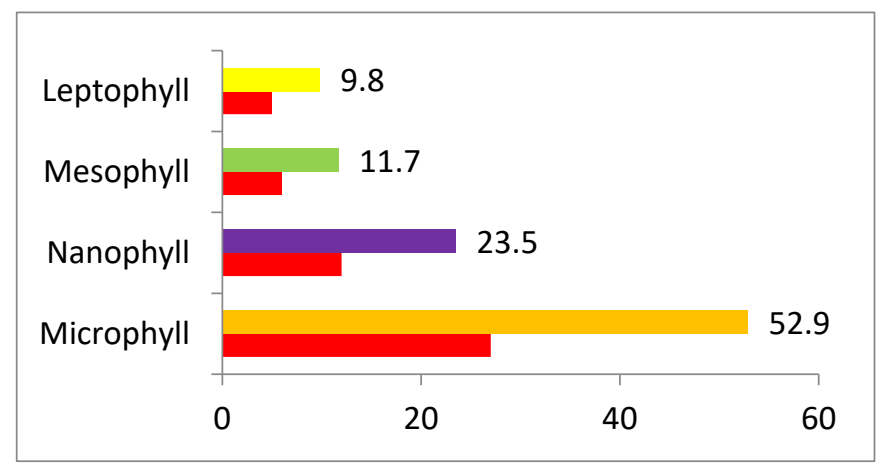

Figure 4 Leaf size spectra of plants recorded from Bara Gali 


\section{DISCUSSION}

There were 50 species and 33 families in study area Asteraceae, Rosaceae and Pteridaceae were dominant families. In study area Hemicryptophytes were dominant. Hemicrytophtes are the indicator of moist temperate zone. Khan et al. (2016). Our findings are also agreed with Malik et al., (1996) observed that in the moist temperate part of Dherkot and Neelam valley of Kashmir, hemicryptophytes and therophytes were the dominant life form classes. Malik (2005) reported hemicryptophytes and therophytes species were dominant in Ganga Choti and Bedori hills at an elevation of 2000-3200m. Malik et al. (2007) reported that hemicryptophytes and therophytes were dominant in Pir Chinasi hills. Due to deforestation and other human activities growth of vegetation in the study area was badly affected.

Microphyll and Nanophyll are the dominant leaf spectra of the explored area. Nanophyll were present at lower altitude while Microphyll were present at higher altitude. Our findings are similar to Qadir and Tareen (1987) who worked in Quetta and reported that Microphyll and Nanophyll were dominant leaf size spectra in Quetta district. Malik (2005) worked in Ganga Chotti and Bedori hills (A.J.K) and reported that Microphyll and Nanophyll were dominant so our result also agreed with this report. Our results also in line with Hussain et al., (2015) who reported dominant leaf size spectra as microphyll and Nanophyllous from Mastuj Valley, Chitral, Pakistan. Shaheen et al. (2016) also reported similar findings from Tehsil Havelian (Abbottabad), Pakistan.

The leaf structure, generally determines habitat condition in the area. The Present research study reveals that microphyll and nanophyll were present at higher elevations while leptophylls present in the lower elevation of Bara Gali. Malik (2005) also described microphyll \& nanophyll were dominant at Ganga Choti and Bedori hills, Kashmir. His findings are in line with our results. In our research study, high ratio of microphylls signifies the cool climate. Malik (2007) reported similar findings from Pir Chinasi Hills, Kashmir. Saxena and Singh (1982) observed that the percentage of microphyll had positive correlation with the growing elevation. In explored area grazing and lopping of fodder was common. Many medicinal plants become the feed of animals. This study helps us in understanding physiological processes of plants.

\section{REFERENCES}

Batalha, M.A. and F.R. Martins. (2004). Floristic, frequency, and vegetation life-form spectra of a Cerrado site. Braz. J. Biol., 64(2) : 203-209. Retrieved from https://doi.org/10.1590/S1519-69842004000200004

Black C.A. (1965). Methods of soil analysis part-II Am. Soci. Agron. Inc. Modison, Wichconisin U.S.A. $\quad$ Retrieved from https://doi.org/10.2134/agronmonogr9.1

Cox W.G. (1967). Laboratory manual of general ecology. WMC Brown Co. Dubuque, Lowa USA.

Curtis M.J. (2000). Ecological evaluation of some rangeland plants of Harboi hills, Kalat, Balochistan. Ph.D thesis University of Peshawar.

Kent, M. (2011). Vegetation description and data analysis: A practical approach. John Wiley \& Sons, $414 \mathrm{pp}$.

Khan. W., S.M. Khan and H. Ahmad. (2015). Altitudinal Variation in Plant Species Diversity and Its Components at Thandiani Sub Forests Division, 


\begin{abstract}
Abbottabad, Pakistan. JBES, ISSN : 2220-6663 (Print) 2222-3045 (Online),
7: 46-53. Retrieved from

https://d1wqtxts1xzle7.cloudfront.net/53983866/Altitudinal_variation_in _plant_species_r20170726-32353-xwfr8y-with-cover-page-

v2.pdf?Expires $=1639733496 \&$ Signature $=$ YE6CfdukZyMaiSPakfznsn2Ieqz1

ouTKc42LzX2x2SX4e2RRI0bd0qa0lNpintUwuMqxgcmnkB6-

65HbptVP EwjZDaPJdETv-

RRT80eqtyDzEkkxNZD seWMnm7vUYAKaZA1K5Q92DeTw1Kx55pjhdupi c0YQ6D1iAcQ-

Uvyyy1eF8iFG6ZVSLsHFGGAbq04ahUdv4W0whJquUehrAYgapFVEaf2Jj0p

88aZIlro0ZRK6Q4FMPeQ9PCkgOlnTJCDFdQSNOQla5T7aZwMJQFJp0U5kzZ

FvRW7U9veFHVQxYJ 63K5-AmUDd0EfLJ7goTdDELGYzKVWD7x6tK-Fq-

Eg_\&Key-Pair-Id=APKAJLOHF5GGSLRBV4ZA
\end{abstract}

Khan. W., S.M. Khan and H. Ahmad. (2016). Floral Biodiversity and Conservation status of the Himalayan Foothills Region, Thandiani Sub Forests Division, Abbottabad, KPK. Journal of conservation Biology Pakistan, 1(1) : 1-9.

Malik Z. H. (2005). Comparative Study on the vegetation of Ganga Chotti and Behori hills District Bagh, Azad Jammu and Kashmir. Ph.D Thesis, University of Peshawar.

Malik, Z. H. and F. Hussain. (1987). Phytosociological Studies of the vegetation around Muzaffarabad AJK. Mod. Trends PI. Sci. Res., 13-17.

Malik, Z.H., S. Ahmad and F. Hussan. (1994). Present studies of sub-tropical chirpine vegetation of Saani Hills Azad Kashmir. Sci. Khyber, 7 :51-58.

Malik. N.Z., M. Arshad and S. N. Mirza. (2007). Phytosociologically attributes of different plant communities of Pir Chinasi hills of Azad Jammu and Kashmir. Int. J. Agric. Biol. 9 : 569-574. Retrieved from https://agris.fao.org/agrissearch/search.do?recordID=PK2007001156

Malik. Z.H. and F. Hussain. (1987). Phytosociological studies of the vegetation around Muzafarabad AJK. Mod. Trends Pl. Sci. Res., Volume :3-17.

Moodi C.D., H.W. Smith and R. A Mercreeny. (1959). Lab Manual for Soil fertility. State College Washington Mimeograph: 31-39.

Muller D. B. and H. Ellemberg. (1974). Aims and methods of vegetation ecology. John Wiley and Sons. Inc. New York.

Nautiyal, M.C., B.P. Nautiyal and V. Prakash. (2001). Phenology and growth form distribution in an alpine pasture at Tungnath, Garhwal Himalaya. Mt. Res. Dev., 21(2) : 177-183. Retrieved from https://doi.org/10.1659/02764741(2001)021[0168:PAGFDI]2.0.C0;2

Odum E.P. (1971). Fundamentals of Ecology, 3rd edition. W. B. Saunders Co. Philadelphia. $574 \mathrm{pp}$.

Qadir S.A. and R.B. Tareen. (1987). Life form and leaf size spectra of the flora of Quetta Distt. In Ilahi, I and F. Hussain (ends) Modera Trends. Plt. Sci. Res.

Rahbek C. (2005). The role of spatial scale and the perception of large - scale speciesrichness patterns. Ecol. letter, 8:224-239. Retrieved from https://doi.org/10.1111/j.1461-0248.2004.00701.x

Raunkiaer C. (1934). The life form of plants and statistical plants Geography, Clarendon Press Oxford. 623pp. Retrieved from https://www.cabdirect.org/cabdirect/abstract/19340701044

Raunkiear C. (1934). The life forms of plants and statistical plant geography oxford Clurendon press. 
Rohde K. Latitudinal gradients in species diversity, the search for the primary cause. Oikos. (1992) ; 65 :514-527. Retrieved from https://doi.org/10.2307/3545569

Saxena, A.K. and J.S. Singh. (1982). A phytosociological analysis of woody species in forest communities of a part of Kumaun Himalaya. Vegetation. 50 : 3-22. Retrieved from https://doi.org/10.1007/BF00120674

Shah M. and F. Hussain. (2009). Phytosociological study of the vegetation of Hayat Abad District Peshawar. Pak. J. Pl. Sci., 15 (2): 123-128. Retrieved from https://go.gale.com/ps/i.do?id=GALE\%7CA254017389\&sid=googleSchola $r \& v=2.1 \& i t=r \&$ linkaccess $=$ abs \&issn $=1023831 X \& p=A 0 N E \&$ sw $=$ w\&userGro upName=anon $\% 7$ Eacdc227d

Shah. A. (1962) Working Plan for the Galis forests of Hazara district (1962-63 to 1977-78). Pp.1,2.

Shaheen, S., Z. Iqbal, F. Ijaz, J. Alam and I.U. Rahman. (2016). Floristic composition, biological spectrum and phenology of Tehsil Havelian, District Abbottabad, Pakistan. Pak. J. Bot., 48(5) : 1849-1859. Retrieved from https://www.researchgate.net/profile/Jan-Alam-

4/publication/339181613_Biological_spectra_of_vegetation_of/links/5fba 2d5e299bf104cf6af4d2/Biological-spectra-of-vegetation-of.pdf

Shimwell, D.W. (1971). The Description and Classification of Vegetation Sedgwick and Jackson, 322. London.

Tansley A.G. (1920). The classification of vegetation and the concept of development. J. Ecol., 8 : 114 . Retrieved from https://doi.org/10.2307/2255529

Tareen R.B. and S.A. Qadir. (1993). Life form and leaf size spectra of the plant communities of diverse areas ranging from Harnai, Sinjawi to Duki regions of Pakistan. Pak. J. Bot., 25 :83-92.

Todoria, N.P., P. Pokhriyal, P. Uniyal and D.S. Chauhan. (2010). Regeneration status of tree species in forest of Phakot and Pathri Rao watersheds in Garhwal Himalaya. Curr. Sci., 98(2) : 171-175. Retrieved from https://www.jstor.org/stable/24111507 